\title{
THE RELATIONSHIP BETWEEN RELIGIOSITY OF PARENTS AND CHILDREN IN CATHOLICS - THE ROLE OF PARENTS IN ADOLESCENTS RELIGIOUS PRACTICE
}

\author{
Damir Miloš* and Dragan Glavaš
}

Catholic University of Croatia

Zagreb, Croatia

DOI: 10.7906/indecs.19.1.6

Received: 29 April 2020.

Regular article

Accepted: 29 July 2020.

\begin{abstract}
This article is based on the "Religion and Human Rights 2,0" research, a survey carried out in Croatia $(N=1286)$ conducted on high school, Gymnasium, students 17-19 years old. It examines the influence of parents' religiosity on the religious practice of adolescents among Catholics $(N=1097)$. There are three dominant questions to be addressed in the article: a) how much and how does the religiosity of their parents influence the religious practice of young people? b) how much does the religiosity of parents affect the specific dimensions of religious practice (the frequency of prayer, the frequency of going to church) of young people? c) does the impact of the parent's religiosity on the child differ in cases where they are both the same sex and in cases in which they are not? The results, obtained by a series of linear regression analyses show that in a) and b) there is some influence of the religiosity of parents on young people. It is also shown that c) there is a dominant influence of the same-sex parent on the child in this respect (mother-daughter, father-son), while the incentive or compulsion to go to mass shows the effect only in the father-daughter dyad. The findings confirm the importance of parental religiosity for youth religiosity a little bit more for church attendance than for the frequency of prayer. They call for the use of elements of parental religiosity in the research of youth religiosity. They also point to the greater effect of parents' religious beliefs and the importance they attach to their child's religiosity than the coercion/incentive to religious practices.
\end{abstract}

\section{KEY WORDS}

youth religiosity, adolescent Catholics, parental religiosity, religiosity of parents

\section{CLASSIFICATION}

JEL: Z12 


\section{INTRODUCTION}

The impression of "eluding religion" in the face of trying to define it, to understand it and explore it weakens when we approach it in a way suggested by Esad Ćimić in 1988. "There are three possible levels of approach to religion, i.e. there are three basic forms of existence of religion: religion per se, religion as a socio-historical fact and religion as a personal experience. Religion per se is the ideal form of the existence of religion. It does not exclude and renounce the value of historical and personal forms of the appearance of religion, but rather designs them, serving them as a benchmark. Religion in itself is an ideal option that constantly reminds us of the difference between sacred and secular. Entering social and historical life, religion takes on the qualities of the world and its laws. Then we talk about religion as a socio-historical fact"... [1; p.854] "Personal religious experience is a substrate of non-church religiosity. Religion as a personal experience implies the level of an individual who can understand a religious message only when he lets it through the filter of his own time-changing experience" $[1 ; \mathrm{p} .854]$. The most common definitions are reduced to the first two (lower) levels. One of these is English \& English's "A system of understanding, belief, behavior, rituals and ceremonies by which an individual or community puts themselves in a relationship with God or with the supernatural world and often in a relationship with one another, and from which (the system) a religious person receives a series of values according to which the natural world is governed and judged [2; p.21]. Religion, in sociology, is most often defined in two ways: substantively and functionalist ${ }^{P}$. The first approach is characterized by an attempt to unify all common (essential) elements without which religion cannot exist. The most famous such definition is that of Durkheim: "Religion is a strongly connected system of beliefs and customs that refers to the holy, that is, separate and forbidden things, namely a system of beliefs and customs that unite all their adherents into the same moral community called the church" [3; p.101]. The role of religion in society, at the time of the emergence of discipline (and today) seemed fundamental and omnipresent, it received a lot of attention from the "founding fathers" of sociology and this is evident in the fact that all of them wrote about it. The social role of religion found its place in the texts of Comte, Durkheim, Simmel, Marx and Weber, as well some later sociological classics such as Parsons and Luhmann [4]. The understanding of its function was different in each of them, from integrative (Comte, Durkheim, Parsons), enslaving (Marx), socio-transformative (Weber) to psychological (Freud, Marx, Durkheim). For sociologists, religion can be researched in the immanence, i.e. in elements of social practices, experiences, rituals, symbols, beliefs and knowledge.

Religiosity, on the other hand, is what Simmel described as "a life's drive... subjective experience of connection with the secretive code of life itself" [5; p.63]. It is necessary to distinguish the concepts of religion and religiosity. "While the concept of religion implies a whole system of ideas, beliefs, and values, the concept of religiosity implies a subjective, individual attitude that arises as a result of the adoption of certain religious beliefs, and which does not have to be associated with only one particular religion (which is the case in new religious movements). Religion is external, public, objective, established and rational, religiosity is internal, private, subjective and emotional" [1; p.854]. Religiosity means the subjective dimension of belonging to a religion. Authors such as Hood Jr., Hill and Spilka count as many as 46 different instruments for measuring religiosity [6; pp.40-41], and this article will specifically explore one of its dimensions by an instrument constructed by Glock and Stark [7]. This instrument is multidimensional and approaches religiosity as a complex phenomenon whose components do not necessarily have to be inter-independent or related, and they are: a) Knowledge (intellectual dimension), b) practice - dimension relating to binding religious practices (mass, prayer, confession, etc.), c) belief - common religious beliefs of members of a religion, d) experience - feelings that a person associates with a 
religious experience (intensity and quality can be very different), e) consequences - a reflection of other dimensions of the daily life and lifestyle of the individual, understanding themselves and others and acting accordingly [2, 4, 5, 8, 9].

Several research studies conducted on religiosity in Croatia were dedicated to the subject of religiosity in the general sense. Some of these will be presented later. This article, however, will be specifically dedicated to the relationship of religiosity of parents and the religiosity of their children.

Other than this relationship, what is there to be seen in terms of the relationship of the type of religiosity that is recognizable in parents and the religious practices of young people? More precisely, can young people be expected to practice religious rituals more if they are encouraged/coerced by their parents to do so, or is it more reliable in this sense to rely on how much of a role religion plays in their parents' lives? Furthermore, the question is, does the religiosity of parents have the same effect on both genders of youth? Is there any role played by the parent's gender and the gender of the child? If we articulate these questions as objectives that this article is trying to achieve, they are a) to investigate whether the religiosity of parents shows an effect on the religious practice of children, if so b) in what way, c) whether this effect differs if we take into account the gender of the child and d) whether the parent's gender is relevant. To answer these questions, the following briefly outlines the broader religious picture of Croatian society with a special emphasis on Catholicism, then an overview of the indicative research on (primary) religious socialization and its effects and its reception mechanism is presented. Finally, we show the results of the survey in light of these studies and the expectations based on them. The results and findings of this study should indicate the importance of including the religiosity of parents in future research of the religiosity of young people, to take into account which parental techniques (or characteristics of parental style) show effects on the religiosity of young people. They should also open up space for further examination of how much and what kind of impact perception and "playing" of parental roles have in the context of religious socialization regarding the gender of the child.

\section{RELIGIOSITY AND RELIGIOUS SOCIALIZATION IN CROATIA}

Croatia is a religiously-homogeneous country. Catholics as a religious group have been the dominant majority for many years with more than $75 \%$ of the population, and in the last 20 years, this proportion is closer to $90 \%$ (87,9 \% according to the 2001 census and 86,3\% in 2011 census $)^{2}$. In a society of such a distinct cultural characteristic, it would be unusual not to recognize it in the practices, institutions, rituals and daily lives of its members. Catholic religious teaching is an elective school subject, Catholic holidays are non-working days, institutions of humanitarian character (Caritas) operate, religious rites of transition are highly represented, Catholic media are active and free, as well as declarative towards Catholic social movements, etc. In short, Catholicism permeates Croatian society on multiple levels. Previous research has shown this, and it is particularly reflected in the acceptance of religious rites of transition (at birth, marriage, and death) even in those who declare themselves non-religious and atheists [10-12]. Extensive research on young people 15 years ago showed that $79 \%$ of young people (15-29 years) attended Catholic religious teaching, and $69,5 \%$ said they were sending or would send their children to same [13; p.90]. European Values Study has also shown that in terms of religious rituals $25-30 \%$ of Croats go to Mass once a week or more often. 31,4 \% in 1999 and 26,4 \% in 2008, while 55-60\% pray more than once a week $(60,1 \%$ in 1999 and 55,2 \% in 2008), with around a third of them $(37,3 \%$ in 1999 and $32,6 \%$ in 2008) praying every day [14; p.451, 456]. It is important to point out that in 1999 around $10 \%$ of Croats prayed with their family once a week or more often (every Sunday or daily), about $50 \%$ on special occasions (holidays, baptism, death) and 39,6\% had never prayed together or did not pray at all. Attention is also drawn to the fact that religious teaching in the family was highlighted as important in $79,6 \%$ of respondents $(84,9 \%$ in Catholics) and was an essential part of traditional educational values [15], while $37 \%$ in 2008 felt that it was especially 
important for children to learn religious beliefs in the family ${ }^{3}$. Research by Leutar and Josipović [16] shows that about $76 \%$ of young people (Faculty of Philosophy of the Society of Jesus) pray regularly or often and about $52 \%$ of them go to mass once a week. All the data presented here outlines the context of religious socialization in Croatia; therefore, socialization in the Catholic spirit will intersect all dimensions of society and, especially important in this work, family.

\section{PARENTAL RELIGIOUS SOCIALIZATION AND SOCIAL LEARNING THEORY}

Society socializes its members through its institutions and actors in social reality. Individuals learn the rules of the game (norms) in society or its relatively bounded spheres through family, school, friends, acquaintances, church, media, professional groups, etc. It is a process by which society maintains and allows the transfer of culture between generations. It can be seen in two ways: a) as a process by which an individual adopts social rules themselves and accepts them as part of their personality, b) a process in which individuals direct their actions according to the expectations of others (in the second part of this article it is clear that in this study the emphasis is precisely on this process of external "socialization pressure") [17; p.363]. When individuals accept these "rules of the game" as their own, we say they've internalized them. Religious socialization is therefore about nurturing values and learning and adhering to the norms of a religion. It takes place in a different way and a different environment through different agents, e.g. in the family - by praying together, celebrating religious holidays, reading holy books, talking about religious topics; in school - by religious education, etc. Primary socialization, i.e. the process by which language and culture are taught in the family, is crucial for the further course of the individual's life, which means that their life is permanently marked by who and what their parents are, what they teach the child and how they teach them, how they treat them, etc. Although primary socialization refers to childhood, family, and especially parental socialization, influence does not cease with the end of childhood. Parents will leave a strong influence on the characteristics and behaviors of their children, reflected in sayings such as "the apple does not fall far from the tree" and "like father, like son". One could expect that religious parents would wish for their children to be religious too (although it does not have to be that way).

These are the issues that are addressed by the social learning theory $[18,19]$ which implies that people learn to behave by "modelling" towards those they look up to or those who provide them with ideas and ideals essential for achieving their desired goal [6]. Such role models are provided by all the agents of socialization listed above, and among them parents stand out as the first and most important source of religious socialization (parental religiosity is one of the strongest predictors of adolescent religiosity), and a significant majority of research confirms this [20]. It should be borne in mind that groups of adolescents, especially those belonging to the religious statistical majority are quite specific because there is a noticeable decrease in religiosity compared to other age groups during this period, which makes the examination of parental influence and religiosity a specific task, as evidenced by the large number of studies [6] $]^{4}$. The results for Croatia show the exact opposite. In a study that covered the end of the adolescent period (15-29 years) of life, Marinović Jerolimov [13; p.104] shows that young people are very religious during this period, although not as religious as they were in childhood, which can be read from data that $63 \%$ (2008) - $70 \%$ (1999) of Croats went to Mass once a week or more often when they were 12 years old and $26 \%$ (2008) - $30 \%$ (1999) in the later period of life, which is a decrease of almost $40 \%$ [14; p.450].

\section{OVERVIEW OF RESEARCH ON PARENTAL RELIGIOUS SOCIALIZATION AND RELIGIOSITY OF CHILDREN}

Since the mid-1950s and Allport's study on the mediation of children's identification with parents in the intergenerational transmission of prejudice (1954), a clear one-line research model 
(parents - child) has gained great significance [21; p.11]. Indeed, except for short-term actuality of "Generational gap thesis" which, for the most part, has proved to be inaccurate [22; p.107], the various studies in its conclusions suggest the firm consensus in the assertion that parents influence their children's beliefs and practices, only differ in the degree of this impact [23]. The literature review and available research trends in this direction. Moreover, family (parental religiosity and religious worldview) alongside peers/friends (especially spouses in the case of adults) and church (religious community, religious education) is taken as a part of the "big three" of religious socialization adolescents $[20,24-26]^{5}$. In the long tradition of research, the primary interest in this work - parental socialization has proved to be extremely important in terms of religiosity and religious activities of children in general. Earlier studies showed the whole range of effects of parental religiosity on the religiosity of children from weak, through moderate to strong [23]. In addition to the diversity of results, related but different subjects were examined in these studies (some of them tried to determine whether there was a link between the social and religious values of parents and children, and others how much parental religious practices affected those of children, etc.). Potvin \& Sloan show that adolescents whose parents regularly go to church practice religious rituals five times more often themselves than those whose parents do not go to church or go irregularly, and Hunsberger finds the connection of apostasy and rejection of parental religious teachings [23]. Four years later, together with Bruce, he found that the relevance of religion in the family during childhood was decisive for remaining attached to religion [27]. In a longitudinal study in the US, Wink, Ciciolla, Dillon, and Tracy showed that as they grow up/age, children increasingly embrace the religious values of their parents [6; p.90], but also that religiosity in the post-adolescent years is a good predictor of spirituality in the continuation of life, which is why they claim that spirituality in adulthood/older age is associated with religious socialization at a young age [28; p.1066]. The reason that stands out is that the value congruence, i.e. attribution of a similar level of importance to some value by parents and children is usually high for religious values and low for all of the others [29]. Interestingly, findings of Himmelfarb in 1979 [24], according to Cornwall [24, 30] confirm the "channeling hypothesis", i.e. that parents socialize their children by channeling them into other groups or experiences (such as school and marriage) that will amplify (have an additional impact) what was learned at home and channel them further into similar adult activities $[24 ; \mathrm{p} . \mathrm{nn}]^{6}$. However, recent results from longitudinal studies involving parents and children have shown a strong parental impact on religious beliefs and practices, not only through childhood, but also throughout the lives of children [25], but at an older age when parents are more dependent on the knowledge and information of their children a vice versa process takes place [25].

Most people are likely to say that a role model in terms of social learning for adolescents will be a parent of the same gender and the research generally confirms that thought. On this trail, Troll and Bengtson (1979) find that: 1) fathers have a greater influence on the formation of values in children than mothers, 2) there is a greater similarity in children and parents of the same gender, than in the opposite, c) daughters are more sensitive to the influence of parents than sons [29; p.257]. However, although there are no unambiguous findings on this topic, in most of the studies the assumption is that the relationships of the parent - the child in various dyads (mother-daughter, mother-son, father-daughter, father-son) are specific ${ }^{7}$. The more gender roles are expected to differ in a society, especially in the case of family roles and work roles, whereby such difference can be expected in Croatian society [31], the stronger connection between the same genders of parent and child in terms of the transfer of personality traits, values and behaviors we can expect [29]. In other words, it is more accentuated that the father will serve as an example to the son, and the mother to the daughter in learning appropriate and desirable social practices. 


\section{THE RESEARCH}

The survey "Religion and Human Rights" $(\mathrm{RHR})^{8}$ was conducted in November and December 2014 in more than 25 countries and with 25000 respondents/students, most of them European (see more about the research and project in Appendix A).

\section{SAMPLE AND RESPONDENTS}

Non-probabilistic quota sample was used, consisting of 1286 pupils (out of 13063 pupils from $4^{\text {th }}$ grade) from 20 counties of the Republic of Croatia and the City of Zagreb (more details on sample in Appendix A). We used the deliberate sampling method. Students of grammar schools were proportionally represented in the sample by counties according to the proportion of grammar school students at the state level. $75,4 \%$ of respondents were 18 years old, and 23,4 \% younger while the remaining 1,2\% had turned 19. Girls were represented in the share of $63,6 \%(N=816)$, and boys in 36,4\% $(N=468)$; this is almost the same gender distribution as in grammar schools nationally where girls are represented $62 \%$ to $38 \%$ according to the Croatian Bureau of Statistics ${ }^{9}$. This article refers to Catholics only $(N=1097)$ because they are the main research interest, i.e. their religious practices and religiosity of their parents.

\section{INSTRUMENTS AND METHODS ${ }^{10}$}

Descriptive statistical methods were used in the first part of the study, i.e. a description of the obtained frequencies and the proportion of results in terms of confessional affiliation and religious self-identification, the frequency of going to mass and the frequency of prayer. Confessional affiliation and religious self-identification is presented by a category variable, and respondents were to mark belonging to one of the religious communities offered Roman Catholics, Protestants, Anglicans, Pentecostals, members of another Christian tradition, Muslims, Sunnis, Shiites, Alawites, members of another Islamic tradition, Jews, Buddhists, Hindus, other religious affiliations, religious without belonging to a community, non-religious. The frequency of going to mass was measured by the question: "How often do you participate in religious services in a church or mosque or another place?", the range of answers offered was: 1 - never, 2 - barely ever, 3 - several times a year, 4 - once to three times a month, 5 - once a week, 6 - more than once a week, 7 - once a day, 8 - several times a day, 9 - I do not know. The frequency of prayer was measured by asking: "How often do you pray?" with the same range of possible answers as for the prior question.

In the second part of the research we used an instrument we called the religiosity of parents. It has already been used in the works of Cornwall [24, 30], Myers [32], Ziebertz and Reindl [33] as religious socialization. In most of these articles more variables and different ones than in our case were included, which was especially the case in Myers' [32] $]^{11}$. To distinguish our instrument from the former, a new name was given. It consists of six variables in total (three related to each parent): "How would you describe your mother/father's (or foster parent) faith in God or a higher reality?" with the answers offered: 1 - absolutely unbelieving, 2 - rather unbelieving, 3 doubtful, 4 - believe, 5 - believe absolutely, $(6 \text { - I do not know, } 7 \text { - not applicable })^{12}$; Furthermore, "How important is it to your mother/father (or foster parents) that you adopt their faith/belief?" with possible answers: 1-not at all important, 2 - not important, 3-fairly important, 4 - very important, (5 - I do not know, 6 - not applicable) and "Does your mother/father (or foster parent) want you to attend religious services?" with the answers: 1no, they leave me totally free in this regard, 2- not really, but they do appreciate it, 3-yes, they insist on it, (4 - I don't know, 5 - not applicable).

The religiosity of parents was represented by a set (6) of predictors in the linear regression model that was performed six times. The first two times for all Catholics, where the dependent 
variables were (1) the frequency of going to church and (2) the frequency of prayer. Following the Glock and Stark model these two variables represent religious practice. The other two times were sub-samples separately for boys and girls using the same independent variables.

Thus, the sequence of analysis is first to show the proportion of Catholics in the population surveyed and their frequency of religious practice, both prayer and going to mass. Then, by using inferential statistical methods, i.e. linear regressions, determine 1) the relationship between the religiosity of the parents and the religious practice in young Catholics in both of the examined aspects (in terms of the frequency of going to mass and the frequency of prayer), 2) the relationship between the religiosity of the individual parent and the religious practice of the child in the case of a daughter and son (i.e. on the sub-samples by gender). The analyses were done in IBM's SPSS version 20.

\section{THE RESULTS}

To get an idea of the proportion of young Catholics in the youth population, it is useful to look at the proportion of Catholics in the entire population according to 1999 and 2008 EVS (European Values Study) data.

Table 1. Confessional affiliation and religious self-identification of young people ${ }^{13}$.

\begin{tabular}{|l|c|c|c|}
\hline & EVS 1999. & EVS 2008. & RHR 2014. (17-19 yrs.) \\
\hline Roman Catholics, \% & 86,8 & 80,6 & 85,8 \\
\hline
\end{tabular}

Table 1 shows the percentage of Catholics represented in this sample, they are the target group in this article, and their percentage is slightly higher in the Religion and Human Rights project than that in the entire population recorded in the last wave of EVS. It should be said that this deviation is not great and that it clearly outlines the dominance of Catholics as a confessional group among young people. All the other confessional groups occupy only $2,2 \%$ of the sample, religious without belonging to a community $2,1 \%$, and $9,9 \%$ of respondents expressed as non-religious.

\section{RELIGIOUS PRACTICE OF YOUNG PEOPLE (CATHOLICS)}

If we present components of religious practice according to the frequency of their practice, the results are as follows in the table below.

Table 2. Frequency of going to church and prayer.

\begin{tabular}{|l|c|c|c|c|c|c|}
\hline \multirow{2}{*}{} & \multicolumn{2}{|c|}{ Frequency of going to church } & \multicolumn{3}{|c|}{ Frequency of prayer } \\
\cline { 2 - 7 } & $f$ & $\%$ & Cumulative & $f$ & $\%$ & Cumulative \\
\hline Never & 83 & 8,1 & 8,1 & 26 & 2,5 & 2,5 \\
\hline Barely ever & 129 & 12,6 & 20,8 & 71 & 6,9 & 9,4 \\
\hline Several times a year & 246 & 24,1 & 44,9 & 68 & 6,6 & 16,0 \\
\hline Once to three times a month & 165 & 16,2 & 61,1 & 88 & 8,5 & 24,5 \\
\hline Once a week & 314 & 30,8 & 91,9 & 81 & 7,8 & 32,3 \\
\hline More than once a week & 80 & 7,8 & 99,7 & 143 & 13,8 & 46,2 \\
\hline Once a day & 2 & 0,2 & 99,9 & 401 & 38,8 & 85,0 \\
\hline Several times a day & 1 & 0,1 & 100,0 & 155 & 15,0 & 100,0 \\
\hline Total & 1020 & 100,0 & & 1033 & 100,0 & \\
\hline I do not know & 30 & & & 37 & & \\
\hline No answer & 47 & & & 27 & & \\
\hline $\begin{array}{l}\text { Total with "do not know" } \\
\text { and "unanswered" }\end{array}$ & 1097 & & & 1097 & & \\
\hline
\end{tabular}


Table 2 shows that around $39 \%$ of young Catholics go to mass once a week or more often, while around $75 \%$ pray once a week or more often.

\section{RELIGIOSITY OF PARENTS AND RELIGIOUS PRACTICE OF YOUNG PEOPLE (CATHOLICS)}

In the first case the linear regression model had the frequency of going to mass as a criterion variable, and in the second the frequency of prayer. A set of predictors previously listed under the name of the religiosity of the parents, for the sake of the overview, is somewhat concise and shown below, and both models are presented in the same table for better visibility of the essential elements.

Table 3. Religiosity of parents and frequency of prayer and going to church.

\begin{tabular}{|l|c|c|}
\hline & Frequency of going to church & $\begin{array}{c}\text { Frequency } \\
\text { of prayer }\end{array}$ \\
\hline Believing in God - father & & $0,114^{*}$ \\
\hline Believing in God - mother & & \\
\hline Accepting his beliefs - father & $0,195^{* *}$ & $0,152^{*}$ \\
\hline Accepting her beliefs - mother & $0,186^{* *}$ & $0,126^{*}$ \\
\hline Degree of incentive/coercion to mass - father & & \\
\hline Degree of incentive/coercion to mass - mother & 0,239 & \\
\hline & 0,233 & 0,153 \\
\hline $\mathrm{R}^{2}$ & & 0,146 \\
\hline $\mathrm{Adj}, \mathrm{R}^{2}$ & $* \mathrm{p}<0,05, * * \mathrm{p}<0,005, * * * \mathrm{p}<0,00$ & \\
\hline
\end{tabular}

From this table, by the quantity of variance explained, it is read that the regression model is more appropriate to predict the frequency of attendance at mass (about $23 \%$ of the variance explained) than the frequency of prayer (about $15 \%$ explained variance). All the predictors are positive, which means that the effect of independent variables is the increase in dependent variables (stronger belief of parents, more importance that children adopt their religious beliefs and a higher degree of encouragement results in greater religious practice, i.e. going to mass and prayer). The table also indicates that the best predictor for participation in mass is the importance that the mother attaches to her child accepting her beliefs $(\beta=0,195)$, and then the father's desire to go to mass $(\beta=0,186)$. It is also evident that in addition to the importance that the father $(\beta=0,152)$ and the mother $(\beta=0,126)$ attach to the child accepting their beliefs, the father's faith in God is a good predictor of the frequency of prayer $(\beta=0,114)$. The only common significant predictor for both models is the importance that a mother attaches to a child accepting her beliefs. These results point to several things a) the religiosity of parents shows an effect on the religious practice of adolescents (there is a respectable percentage of variance explained in both cases) b) effect is stronger on the frequency of going to mass than on the frequency of prayer, c) in terms of prayer, the effect of the father's religiosity is somewhat stronger, as it manifests itself in two spheres (the belief and importance it attaches to the child to adopt his beliefs) than the mother's (the importance of accepting her religious beliefs), and d) the importance that the mother assigns to accepting her beliefs and the degree of encouragement/coercion of the father show relevance in attendance at mass. To find out whether the claims c) and d) stand for both genders of adolescents, a more detailed analysis is needed on the subsamples (groups) of young men and girls separately. 


\section{PARENTS’ RELIGIOSITY AND RELIGIOUS PRACTICE BY GENDER}

In the following case, two regression models were used that had the frequency of going to mass for the criterion variable, the first for girls (left column), the second for young men (right column). The religiosity of parents is a set of the same predictors as in the previous case. Both models are in the same table below.

Table 4. Religiosity of parents and frequency of going to church by gender.

\begin{tabular}{|c|c|c|}
\hline & Girls & Boys \\
\hline & \multicolumn{2}{|c|}{ Frequency of going to church } \\
\hline \multicolumn{3}{|l|}{ Believing in God - father } \\
\hline \multicolumn{3}{|l|}{ Believing in God - mother } \\
\hline Accepting his beliefs - father & & $0,313^{*}$ \\
\hline Accepting her beliefs - mother & $0,265 * * *$ & \\
\hline Degree of incentive/coercion to mass - father & $0,230 * *$ & \\
\hline \multicolumn{3}{|l|}{ Degree of incentive/coercion to mass - mother } \\
\hline $\mathrm{R}^{2}$ & 0,244 & 0,248 \\
\hline $\operatorname{Adj}, R^{2}$ & 0,234 & 0,23 \\
\hline \multicolumn{3}{|c|}{${ }^{*} p<0,05, * * p<0,005, * * * p<0,00$} \\
\hline
\end{tabular}

Equally explained variances (about $23 \%$ ) for girls and young men indicate that parental religiosity proves to be important in going to mass equally for both genders. However, the influence of mother and father on boys and girls is different. For boys, a significant predictor $(\beta=0,313)$ is only the importance that the father attaches to the acceptance of his religious beliefs and, for girls, the importance that the mother attaches to the acceptance of her religious beliefs $(\beta=0,265)$ comes first and then the father's incentive/coercion $(\beta=0,230)$. In short, the frequency of going to mass for young men can be foreseen based on how much the father cares for their sons to adopt their religious beliefs, while this practice can be predicted in girls based on the importance that mothers place on their daughters to adopt their religious beliefs. Their father's encouragement/coercion to mass plays a fairly important role in the case of girls.

As in the case of going to church, two regression models were used, only this time the criterion variable was the frequency of prayer. The first for girls (left column), the second for young men (right column). Religiosity of parents is a set of the same predictors as in all previous cases. Both models are shown in the same table (5).

Table 5. Religiosity of parents and frequency of prayer by gender.

\begin{tabular}{|c|c|c|}
\hline & Girls & Boys \\
\hline & \multicolumn{2}{|c|}{ Frequency of prayer } \\
\hline Believing in God - father & & $0,179 *$ \\
\hline Believing in God - mother & $0,141^{*}$ & \\
\hline Accepting his beliefs - father & & $0,235^{*}$ \\
\hline Accepting her beliefs - mother & $0,184 *$ & \\
\hline \multicolumn{3}{|l|}{ Degree of incentive/coercion to mass - father } \\
\hline \multicolumn{3}{|l|}{ Degree of incentive/coercion to mass - mother } \\
\hline $\mathrm{R}^{2}$ & 0,171 & 0,163 \\
\hline Adj, $R^{2}$ & 0,16 & 0,144 \\
\hline \multicolumn{3}{|c|}{${ }^{*} p<0,05,{ }^{* *} p<0,005,{ }^{*} * * p<0,00$} \\
\hline
\end{tabular}


Once again, the religiosity of parents proves equally important for the frequency of prayer in both genders. This time, the dyads effects of parents and same-gender children are clearly seen. The more their mothers expect from girls to adopt their beliefs $(\beta=0,184)$ and believe in God more $(\beta=0,141)$ the more often they pray. The more important it is for their fathers to accept their beliefs $(\beta=0,235)$ and believe in God more, boys pray more $(\beta=0,179)$. It is shown that the incitement/coercion to attend mass does not show an effect on frequency of prayer in any gender. Although some of this betas $(\beta)$ are not particularly strong, they give us clear indication of forming these dyads.

\section{DISCUSSION}

As a general conclusion, it can be drawn that parental religious context plays a very important role in young people's religious practice. It seems like Church attendance as a visible and public ritual owes its share to mothers' "role modeling" and fathers' direct incentive. This can be plainly articulated as soft and hard stimulus from mother and father which somewhat corresponds to stereotypical parental personality traits, namely permissive and gentle mothers vs strict and rough fathers. Since religiousness in the institutional sense (church attendance) represents desirable behavior in Croatia it does not surprise that it's partly a consequence of fathers' direct push for a child to represent his family appropriately i.e. care about its reputation. This also partly explains the weaker relationship of religiosity of parents and frequency of prayer. Forcing someone to prayer does not make any sense and is almost impossible. This kind of intimate act and relationship with God results from more intrinsic factors and habitualized family rituals. Believing in God and accepting parent's beliefs plays a greater role in the frequency of prayer as it presents an inextricable element of the greater family religious context.

Going to church in the case of boys can be seen as the most convincing "religious role modeling" in this research. Young men either look up to their fathers in this sense or modern dads are good at communicating their beliefs to their sons, or both. The same can be said about mothers and daughters in this respect, although the father's coercion/incentive to daughters cannot be left out. It could be stated that fathers "press" girls harder to represent the stereotype of more polite and conformist children in public spaces (church) as this is expected from young girls. On the other hand, it could not be omitted that "it takes two to tango" as young girls do conform to fathers' requirements more. The more conspicuous rebelliousness in creating an autonomy from pater familias could be the reason for the insignificance of this factor in boys' church attendance [34].

If we rule out the degree of incentive or coercion to mass as a factor in prayer frequency because of its analytical and rational disconnectivity, the leftovers are exactly what could be expected. On the one hand, the same gender parent-child relationship should be similar in this regard to that in other spheres of social life such as household and work roles. The greater similarity of social position and expected social behavior (gender roles) from mother and daughter rather than mother and son binds them together and makes them more alike especially because women and men have different roles in some religious rituals. Therefore it can be presumed that young men will look up to their fathers, i.e. young women to mothers as they already know established patterns of behavior well and provide them first-hand experience and example. An important remark considering the weaker relationship of parent's religiosity and their children's prayer frequency is that prayer is more intrinsic and difficult to subject to external social forces, hence it is a reflection of "religious personality" to a greater extent. Generally speaking, the greater efficiency of parental soft stimuli in children religious practice is partly the result of "religious parental style" because it presents religious practices as pleasant and warm (family) activities which do not need emphasized external control and request for obedience [35]. 


\section{LIMITATIONS OF THE RESEARCH}

The first restriction and call for caution in generalizing the results arises from the sampling method. The target is a "narrowly focused" age group (17-19 yrs.), and only in one type of secondary school - Gymnasium. For this reason, it should be borne in mind that this work does not apply to all young people. Also, it applies only to those declared as Catholics. The inability of researchers to be in the field and give appropriate instruction for teachers raises the question of ensuring the necessary conditions for filling out questionnaires such as whether the respondents had sufficient time, whether any ambiguities were resolved, and how effective social facilitation or social inhibition could have been due to (un)controlled conditions for filling out the questionnaire. The international character and multinational leadership of the research resulted in the inability to adapt certain variables/questions to the Croatian context, e.g. the example of confessional affiliation/religious self-identification, and examination of perceptions like tension and discrimination between races. In the instruments used, it would not be resentful if they were more substantive. More specifically, the variables (predictors) presented here as the religiosity of parents expressed a) how much do the respondents estimate that the father or mother "believe", i.e. how strong are their religious beliefs, b) how much do the respondents estimate that their parents care to adopt their religious beliefs and c) to what degree they are encouraged/forced to go to church. The question arises as to how more usable the instrument would have been if it contained more variables about parents' religious practices and family religious activities. Besides, it is to note that the assessment/attribution of the subjects on the religiosity of their parents calls for caution when concluding on the "actual" religiosity of parents, as it may be that respondents exaggerate or underestimate the level of their religiosity ${ }^{14}$. The longitudinal character would largely be helpful in research such as this, as it could make it possible to monitor variability in the religiosity of the subjects on the one hand, and their parents on the other as well as their interaction at various periods of life.

\section{CONCLUSION}

Firstly, it is pointed out that the number of people who declare themselves as Roman Catholic in Croatia is stable, at least since 1999 and is between $80 \%$ and $90 \%$ of the population. In this case, in the age group of high schoolers (17-19 years old) it is 85,8\%. Although the period of adolescence in comparison to childhood is a period of decline in the frequency of the practice of religious practices, it is also more intense compared to mature age, and grows again in old age $[14,36]$. The frequency of going to mass once a week or more often is for Catholics as it was in 2002 for this age group (38\%) and all confessional affiliations [13]. A share of $39 \%$ indicates the relative stability of attendance of mass in young people over the last 15 years (although this data could differ if all high school students were surveyed). Furthermore, the data on $75 \%$ of the subjects praying once a week or more often seems quite large, but again it is (only) about Catholics in an age group for which a high degree of religiosity ${ }^{15}$ is characteristic. In other words, young Catholics are quite religious and this is primarily seen in the frequency of prayer. Such a large gap between the frequency of going to mass and praying can be explained by an aversion to institutionalized (or ecclesiastical) forms of religiosity which favour Baloban's thesis on declining and distant ecclesiolatry [12], and the feature of prayer as a private act that is direct and personal communication with God.

The results of the relationship between parents' religiosity and the religious practice of young people can be summed up by the following assertions: a) the more religious parents are, the more importance they give that their children adopt their religious beliefs, the more frequent religious practice among young Catholics is, b) their influence is greater in terms of going to mass than on the frequency of prayer, c) the practically exclusive dyads of father-son and mother-daughter crystallized, i.e. the religiosity of mothers and the importance they place on 
their daughters to adopt their beliefs are reflected in prayer and going to mass, the same being the case in the relationship between father and son, d) the degree of incentive or coercion of parents for their children to attend mass shows an effect only in the case of father-daughter.

The results summarized in a) remind us that family, namely, parents are still a strong factor in the religiosity of young people. This can be concluded because the percentage of variance explained is high, considering only six selected predictors. In fact, a number of other studies presented in the article included far more elements of family religious socialization like how often parents pray and go to church, how often they read the Bible, religious texts, and watch religious media shows, how much they agree on their religious beliefs, etc. In addition to religiosity and religious practices of parents, as Roberts and Yamane [26; pp.95-97] show, the quality of family relationships (warmth, closeness, and marital happiness), the unity of tradition (common confessional belonging of parents) and the stability of the family structure (both biological parents) are important for the outcomes of religious socialization. The transfer of values in the family, and consequent practice of children is influenced by its position in social stratification and class status [37] as well as cultural specificities of some society [37]. Even without these all these, factors that included $23 \%$ variance for going to church and $15 \%$ for prayer were explained in this study.

The rationale for claim b) can go in at least two directions: 1) it is easier for parents to gain a greater degree of control over going to mass, 2) a rare common prayer in the family provides less opportunity for a stable pattern of behavior. Findings in c) and d) point towards the conclusion that parents serve primarily as a model for learning to children of the same gender in terms of religious socialization. This could be assumed in the context of the previous research and findings presented above on the high probability of transfer of values and patterns of behavior in same-gender dyads typical of societies with relatively separate gender roles [29, 31]. However, it indicates that the degree of encouragement/coercion of going to church shows only the effect on girls by fathers, which can be attributed to the generally increased restrictive control of girls at that age $[22,35]$. In this context, in future research, repercussions of elements of parental style such as authoritarianism, but also the personality traits of children such as conformism, authoritarianism, and rebelliousness in the exploration of religiosity should be taken into account.

\section{REMARKS}

${ }^{1}$ For more on the topic, see Dillon [38], Zrinščak [39], Beyer [40; pp.45-60].

${ }^{2}$ In 1991, two censuses were conducted, one Yugoslavian and one after the independence of the Republic of Croatia, with both accounting Catholics for just over $75 \%$ of the population. Data for 2001 and 2011 was obtained from http://www.dzs.hr and are accessible in the category of "population censuses" (accessed 25.10.2017).

${ }^{3}$ From EVS, 2008, as shown in http://www.atlasofeuropeanvalues.eu/new/europa.php ?ids $=178 \&$ year $=2008 \&$ country $=$ HR , accessed $25^{\text {th }}$ October 2017.

${ }^{4}$ The data relates to North America and Europe.

${ }^{5}$ For the full list here should be added school, religious community, religious tradition, and media, namely it turns out that everyone in the literature recognizes the agents of socialization important in different contexts, whilst parental religious socialization is the most reliable and persuasive predictor of the religiosity of adolescents.

${ }^{6}$ The page number cannot be entered because it is an online version of the book: Thomas, D.L., ed.: The Religion and Family Connection: Social Science Perspectives. [41], available at https://rsc.byu.edu/archived/religion-and-family-connection-social-science-perspectives/ chapter-11-influence-three, accessed 25th October 2017. 
${ }^{7}$ Russell \& Saebel [42] warn, therefore, of three groups of factors that significantly affect them: a) The individual characteristics of children such as gender, age, temperament, and social competences; b) Individual characteristics of parents such as personality, social competences, gender and belief, and values; c) Socio-contextual factors such as the type and quality of the marital relationship, sources of stress, social networks and the level of support.

${ }^{8}$ Data in this survey obtained from the international project "Religion and Human Rights", more details on: http://www.rp.theologie.uni-wuerzburg.de/research/religion_and_human_r ights_2012_2019.

${ }^{9}$ Statistical Press release, April 2014, https://www.dzs.hr/Hrv_Eng/publication/2014/SI1521.pdf, accessed 30 ${ }^{\text {th }}$ March 2020.

${ }^{10}$ The questionnaire was standardized by an international team of experts so that the scales and instrument are not exactly in line with the local tradition of measuring confessional affiliation and religious self-identification by two variables.

${ }^{11}$ Contains questions/variables: 1) Daily influence of religious beliefs, 2) Bible reading frequency, 3) Frequency of viewing of religious TV shows, 4) Frequency of prayer, 5) Frequency of participation in church-related activities (excluding Mass), 6) Frequency of going to Mass [33; p.861].

${ }^{12}$ Values in parentheses are excluded from the analysis (in the first two questions under 6 and 7, the other two under 5 and 6 and in the fifth and sixth under 4 and 5).

${ }^{13}$ EVS data available in: Rimac [14; p.449].

${ }^{14}$ Illustrative case in this sense is the research of Acock and Bengston [43] indicating the discrepancy between the children's perception of their parents on the series of social, political and religious questions and the "real" answers (scores) of the parents.

${ }^{15}$ See Marinović Jerolimov, [13; p.104].

\section{APPENDIX A - DETAILS ABOUT THE RESEARCH AND SAMPLING}

The project was funded by the University of Würzburg and it aimed at: a) discovering theoretical and socially relevant relationships (religious beliefs and practices) and attitudes towards human rights, b) determining the direction of these relationships as regards the influence of religion on attitudes to human rights, c) analyzing differences within and between religious groups and countries of northern, western, eastern and southern Europe, d) theoretically and empirically formulating legitimate hypotheses on the influence of religion on human rights attitudes that will be tested in future research. About 1,300 respondents participated in the survey in Croatia. Because the target group was young, high school students who were assumed to continue their education and fill prominent places in society, project managers decided to choose grammar school students for respondents. In the words of the project manager "we chose young people for the target group... because this population is a litmus paper that outlines social trends well ..." [44; p.VII]. In total, 45 grammar school fourth grades participated in the survey. Questionnaires were sent by mail. For each gymnasium that participated in the survey, written consents from their principals were obtained. Questionnaire fulfillment was conducted in class, during the social sciences and religious education classes. The questionnaire instructions were accompanied by a questionnaire package and were further clarified by telephone in the event of ambiguity. Responding time was 45 minutes. The questionnaire contained 211 questions divided into thematic blocks on confessional affiliation, religiosity, the public role of the church, attitudes towards human rights, values, political orientation, the scale of authoritarianism, orientation to social domination, empathy, trust in social and state institutions and the perception of justice etc. The answers to these questions were given on the Likert scales of five or sevendegree stacking. Among these questions was a block of questions about the sociodemographic 
Table 6. Characteristics of the sample.

\begin{tabular}{|l|c|c|}
\hline \multicolumn{1}{|c|}{ County name } & Sample share, $\%$ & Frequency, of respondents \\
\hline The City of Zagreb & 27,5 & 354 \\
\hline Splitsko-dalmatinska & 14,2 & 149 \\
\hline Osiječko-baranjska & 7,3 & 94 \\
\hline Zadarska & 5,6 & 62 \\
\hline Zagrebačka & 4,7 & 61 \\
\hline Primorsko-goranska & 4,7 & 60 \\
\hline Dubrovačko-neretvanska & 4,6 & 59 \\
\hline Istarska & 3,9 & 50 \\
\hline Vukovarsko-srijemska & 3,4 & 44 \\
\hline Brodsko-posavska & 2,7 & 35 \\
\hline Sisačko-moslavačka & 2,5 & 32 \\
\hline Koprivničko-križevačka & 2,4 & 31 \\
\hline Međimurska & 2,3 & 30 \\
\hline Krapinsko-zagorska & 2,3 & 30 \\
\hline Šibensko-kninska & 2,3 & 30 \\
\hline Požeško-slavonska & 2,3 & 30 \\
\hline Karlovačka & 2,3 & 30 \\
\hline Bjelovarsko-bilogorska & 2,2 & 28 \\
\hline Virovitičko-podravska & 1,9 & 24 \\
\hline Varaždinska & 1,7 & 22 \\
\hline
\end{tabular}

characteristics of subjects such as gender, age, city of high school attendance, mother tongue and country of birth, parents' education levels.

Ličko-senjska County was omitted from the sample because only five respondents were available.

\section{REFERENCES}

[1] Marinović Bobinac, A.: Non-church religiosity in Croatia. In Croatian.

Društvena istraživanja 4(6), 853-866, 1995 ,

[2] Ćorić, Š.Š.: Psychology of religiosity. In Croatian.

Naklada Slap, Jastrebarsko, 2003,

[3] Durkheim, E.: Elementary forms of religious life. In Croatian.

Jesenski i Turk, Zagreb, 2008,

[4] Knoblauch, H.: Sociology of Religion. In Croatian.

Demetra, Zagreb, 2004,

[5] Acquaviva, S. and Enzo, P.: Sociology of Religion - Problems and Perspectives. In Croatian. Societas, Zagreb, 1996,

[6] Hood, R.W.; Hill, P.C. and Spilka, B.: The Psychology of Religion.

The Guilford Press, New York, 2009,

[7] Glock, C.Y. and Stark, R.: American Piety: The Nature of Religious Commitment. University of Califorina Press, Berkeley and Los Angeles, 1968,

[8] Marinović Bobinac, A.: The consequent dimension of religiosity. In Croatian. Sociologija sela (38), 111-124, 2000,

[9] Marinović Jerolimov, D. : Multidimensional approach in the research of religiosity: Guidelines for research in Croatia. In Croatian.

Društvena istraživanja 4(6), 837-852, 1995,

[10] Črpić, G. and Kušar, S.: Some aspects of religiosity in Croatia. In Croatian. Bogoslovska smotra 68(4), 513-563, 1998, http://dx.doi.org/10.1086/603019, 
[11] Baloban, J. and Črpić, G.: Certain aspects of ecclesiology. In Croatian. Bogoslovska smotra 70(2), 257-290, 2000, http://dx.doi.org/10.1126/science.290.5490.257,

[12] Crnić, D.: Ritual dimension of ecclesiology in Croatia. In Croatian. Riječki teološki časopis 20(1), 87-102, 2012, http://dx.doi.org/10.1080/0907676X.2011.632683,

[13] Marinović Jerolimov, D.: Religiosity, non-religiousness and some values of young people. In Croatian.

In: Furio R., et al.: Mladi uoči tré́eg milenija. Institut za društvena istraživanja u Zagrebu, Zagreb, pp.79-125., 2002,

[14] Rimac, I.: Comparative Review of Answers to Questions in the 1999 and 2008 European Values Survey. In Croatian.

Bogoslovska smotra 80(2), 425-525, 2010, http://dx.doi.org/10.1016/j.carbpol.2009.12.020,

[15] Črpić, G. and Hoblaj, A.: Essential values in the education of young generations with special reference to school religious education. In Croatian.

Bogoslovska smotra 70(2), 359-393, 2000, http://dx.doi.org/10.3366/afr.2000.70.3.359,

[16] Leutar, Z. and Josipović, A.M.: Some dimensions of youth religiosity. In Croatian. Nova prisutnost 6(3), 373-395, 2008,

[17] Abercrombie, N.; Hill, S. and Turner, B.S.: The Penguin Dictionary of Sociology. Penguin Books, London, 2006,

[18] Bandura, A.: Social learning theory. Prentice Hall, Englewood Cliffs, 1977,

[19] Bandura, A: Social foundations of thought and action: A social cognitive theory. Prentice-Hall, Upper Saddle River, New Jersey, 1986,

[20] Yamane, D.: Handbook of Religion and Society. Springer, Switzerland, 2016,

[21] Schönpflug, U.: Cultural Transmission: Psychological, Developmental, Social, and Methodological Aspects. Cambridge University Press, Cambridge, 2009,

[22] Lacković Grgin, K.: Psychology of adolescence. In Croatian. Naklada Slap, Jasterbarsko, 2006,

[23] Stott, G.N.: Familial Influence on Religious Involvement. In: Darwin L.T.: The Religion and Family Connection: Social Science Perspectives. UT, Religious Studies Center, Brigham Young University, Provo, pp.258-271, 1988,

[24] Cornwall, M.: The Influence of Three Agents of Religious Socialization: Family, Church, and Peers.

In: Thomas, D.L.: The Religion and Family Connection: Social Science Perspectives. Religious Studies Center, Brigham Young University, Provop, pp.207-231, 1988,

[25] Sherkat, D.E.: Sources of Influence and Influences of Agency. In: Delanty, G. and Isin, E.F.: Handbook of the Sociology. Cambridge University Press, Cambridge, pp.151-163, 2003,

[26] Roberts, K.A. and Yamane, D.: Religion in Sociological Perspective. SAGE Publications, Los Angeles, 2011,

[27] Hunsberger, B. and Brown, L.B.: Religious Socialization, Apostasy, and the Impact of Family Background.

Journal for the Scientific Study of Religion 23(3) 239-251, 1984, http://dx.doi.org/10.2307/1386039,

[28] Wink, P.; Ciciolla, L.; Dillon, M. and Tracy, A.: Religiousness, Spiritual Seeking, and Personality: Findings from a Longitudinal Study.

Journal of Personality 5, 1052-1070, 2007, 
[29] Knafo, A. and Schwartz, S.H.: Accounting for Parent-Child Value Congruence: Theoretical Considerations and Empirical Evidence.

In: Schönpflug, U., ed.: Cultural Transmission- Psychological, Developmental, Social, and Methodological Aspects. Cambridge University Press, Cambridge, pp.240-268, 2009,

[30] Cornwall, M.: The Determinants of Religious Behavior: A Theoretical Model and Empirical Test.

Social Forces 68(2), 572-592, 1989, http://dx.doi.org/10.1093/sf/68.2.572,

[31] Brajdić Vuković, M.; Birkelund, G.E. and Štulhofer, A.: Between Tradition and Modernization: Attitudes Toward Women's Employment and Gender Roles in Croatia. International Journal of Sociology 37(3), 32-53, 2007, http://dx.doi.org/10.2753/IJS0020-76593703002,

[32] Myers, S.M.: An Interactive Model of Religiosity Inheritance: The Importance of Family Context.

American Sociological Review 61(5), 858-866, 1996, http://dx.doi.org/10.2307/2096457,

[33] Ziebertz, H.G. and Reindl, M.: Religious Socialisation and Values as Predictors of Human Rights Attitudes: An Empirical Study among Christian and Muslim Adolescents in Germany.

In: van der Ven, J.A. and Ziebertz, H.G., eds.: Tensions within and between Religions and Human Rights. Lieden, Brill, pp.223-224, 2012,

[34] Berk, L.E.: Development through the Lifespan. In Croatian.

Naklada Slap, Jasterbarsko, 2008,

[35] Čudina Obradović, M. and Obradović, J.: Psychology of marriage and family. In Croatian. Golden marketing - Tehnička knjiga, Zagreb, 2006,

[36] Bezinović, P.; Marinović Bobinac, A. and Marinović Jerolimov, D.: Short scale of religiosity: validation on a sample of adolescents. In Croatian.

Društvena istraživanja 14(1-2), 135-153, 2005,

[37] Hitlin, S.: Parental Influences on Children's Values and Aspirations: Bridging Two Theories of Social Class and Socialization.

Sociological Perspectives 49(1), 25-46, 2006, http://dx.doi.org/10.1525/sop.2006.49.1.25,

[38] Dillon, M.: Handbook of the Sociology. Cambridge University Press, Cambridge, 2003,

[39] Zrinščak, S.: What is religion and why religion: a sociological approach. In Croatian. Bogoslovska smotra 78(1), 25-37, 2008, http://dx.doi.org/10.1016/S0212-8241(08)70869-7,

[40] Beyer, P.: Social Forms of Religion and Religions in Contemporary Global Society. In: Dillon, M.: Handbook of the Sociology of Religion.

Cambridge University Press, Cambridge, pp.45-60, 2003,

[41] Thomas, D.L.: The Religion and Family Connection: Social Science Perspectives. Religious Studies Center, Brigham Young University, Provo, Utah, 1988,

[42] Russel, A. and Saebel, J.: Mother-Son, Mother-Daughter, Father-Son, and Father-Daughter: Are They Distinct Relationships?

Developmental Review 97, 111-147, 1997, http://dx.doi.org/10.1023/A:1004918402670,

[43] Acock, A.C. and Bengston, V.L.: Socialization and Attribution Processes: Actual versus Perceived Similarity among Parents and Youth.

Journal of Marriage and Family 42(3), 501-515, 1980, http://dx.doi.org/10.2307/351895,

[44] Ziebertz, H.G.: Preface.

In: Religion and Human Rights. Springer, Heidelberg, pp.v-viii, 2015. 